\title{
GIS-BASED HYDROLOGICAL MODELLING USING SWAT: CASE STUDY OF UPSTREAM WATERSHED OF JEBBA RESERVOIR IN NIGERIA
}

\author{
A.G. Adeogun ${ }^{1 *}$, B. F. Sule ${ }^{2}$, A.W. Salami ${ }^{3}$ and 0.G. Okeola ${ }^{4}$ \\ 1,2 NATIONAL CENTRE FOR HYDROPOWER RESEARCH AND DEVELOPMENT, UNIVERSITY OF ILORIN, NIGERIA \\ 3,4DEPARTMENT OF CIVIL ENGINEERING, UNIVERSITY OF ILORIN P.M.B 1515, ILORIN, NIGERIA \\ E-mail addresses:11niyiadeogun@gmail.com, ${ }^{2}$ bfsuleiman@gmail.com,3salami_wahab@unilorun.edu.ng \\ 4 okeolaolayinka@gmail.com
}

\begin{abstract}
Hydrological modeling tools have been increasingly used worldwide in the management of water resources at watershed level. The application of these tools have been improved in recent time through the advent of remote sensing and Geographical Information System (GIS) techniques which enhance the use of spatially and physically based models to simulate and predict some of the major functions of watershed systems. In this study, the focus was on the applicability and feasibility of SWAT model interfaced with GIS software (MapWindow) in the prediction of stream flow of a watershed located upstream of Jebba reservoir in Nigeria. The flow predictions by SWAT were calibrated (from Jan. 1990 to Dec. 1992) and validated (from Jan.1993 to Dec.1995) against measured flow data while the performance evaluation of the model was achieved using coefficient of determination $R^{2}$ and NaschSutcliffe Efficiency (NSE). Sensitivity analysis of the model parameters showed that curve number is the most sensitive parameter for estimation of stream flow within the catchment. The model results showed a good correlation with the observed data with values of 0.76 for $R^{2}$ and 0.72 for NSE during calibration period. For validation periods, $R^{2}$ and NSE values were 0.71 and 0.78 respectively. This interesting results of SWAT is an indication that a properly calibrated SWAT can be an ideal modeling tool for supporting water resources management policies and decisions at watershed level in the region and other river catchments in Nigeria
\end{abstract}

Keywords: GIS, Hydrologic Modeling, Jebba Reservoir, Nigeria, SWAT Model

\section{INTRODUCTION}

The use of hydrological models in the prediction and analysis of flow and erosion processes in a catchment has been on increase in the past decades. Application of these simulation models are usually done at watershed level as this has been widely adopted as a better way of predicting and managing water resources in a sustainable way [1]. In order to improve its effectiveness in terms of data representation and quality of modeling results, hydrological models are usually embedded in Geographical Information System (GIS) environment to simulate various parameters attributed to a selected catchment. GIS is a broad, complex technology highly suitable for spatial and temporal data analyses and information extraction. It is an information system with a database consisting of observations on spatially distributed features or events and procedures to collect, store, retrieve, and display such geographical data [2]. A spatial hydrology model is one which simulates the water flow and transport in a specified region of the earth using GIS data structures [3]. In view of this, the use of modeling tool interfaced with GIS provides the platform to streamline GIS processes tailored towards hydrologic modeling.

Among the widely applied hydrological models for flow prediction in recent time is the Soil and Water Assessment Tool (SWAT). The modeling tool was originally developed by the United States Department of Agriculture (USDA) to predict the impact of land management practices on water, sediment and agricultural chemical yields in large ungauged basins [4]. The model is comprehensive and can be used to assess the impact of land management practice on water, sediment and agricultural chemical yields in large complex basins with varying soil types, land use 
and management conditions. The inbuilt algorithms of SWAT model are useful tools for generating missing climate data for basins [5]. The SWAT model is a physically based semi distributed hydrologic model requiring input data which is difficult to obtain even in developed countries where data of high quality are generally collected and analyzed [6].

Many applications of SWAT model worldwide have shown that it is a versatile tool in the prediction of flow at different watershed scales. A critical review of SWAT applications in the upper Nile Basins countries is provided by [6]. The review is purposely to evaluate various models that have been reported in peerreviewed journal papers in the upper Nile countries by looking at their approaches and methods vis-a-vis what they state to achieve. It covers SWAT applications in countries like Egypt, Sudan, South-Sudan, Ethiopia, Eritrea, Uganda, Tanzania, Kenya, Burundi, Rwanda and DR Congo.

SWAT model has also been applied to model the hydrology in the Bouregreg basin located at the northcentral of Morocco the watershed was modeled by [1] using the Soil and Water Assessment Tool (SWAT) to understand and determine the different watershed hydrological processes. The developed SWAT model were calibrated using an auto-calibration method based on a Shuffled Complex Evolution Algorithm from 1989 to 1997 and validated from 1998 to 2005. It was reported that a good correlation between the observed and simulated monthly average river discharge with $\mathrm{R}^{2}$ and Nash co-efficient of about 0.8 was achieved for the watershed. The evaluation of SWAT model for flow simulation and forecasting in the Upper Bernam humid tropical river basin, Malaysia was carried out by [7]. A good performance in flow simulating as well as forecasting was reported while the study showed the efficacy of SWAT in simulating and forecasting flow in humid tropical condition successfully and can be used to study the effects of future land use changes on flow in the area.

In order to test the applicability of SWAT model in Nigerian river catchment, the upstream watershed of Jebba dam in north central Nigeria was selected as a case study to examine the potentials of SWAT model interfaced with MapWindow GIS to simulate the hydrology and predict the flow in the watershed

\section{MATERIALS AND METHODS}

\subsection{Description of Study Area}

The upstream watershed of Jebba Lake is located in North Central Nigeria between Lat 10.31N Long 5.01E and Lat $8.99 \mathrm{~N}$ Long $4.79 \mathrm{E}$ and has a perimeter of $567 \mathrm{Km}$ and an estimated area of $12,992 \mathrm{~km}^{2}$ (see Figure 1). Major rivers and tributaries within the watershed are River Niger, Awun, Moshi, Eku, Kotongora and Oli. The range of elevation of the watershed is between $114 \mathrm{~m}$ and $403 \mathrm{~m}$ above sea level and the average monthly discharge at Jebba station situated at the outlet of the watershed is $1053 \mathrm{~m}^{3} / \mathrm{s}$ for the period of 1984-2008, with a minimum value of $378 \mathrm{~m}^{3} / \mathrm{s}$ in February 1984 and a maximum value of $3,636 \mathrm{~m}^{3} / \mathrm{s}$ in October,1998. The watershed area is sandwiched between Kainji and Jebba hydropower reservoirs which lie completely in north central Nigeria. The selection of the area to test the applicability of SWAT model is based on the availability of model input data at the Nigeria Metrological Agency (NIMET) and Jebba Hydroelectric PLC. The watershed also plays a predominant role in the national energy supply since it contributes substantially to the water flowing into Jebba lake downstream where about $764 \mathrm{MW}$ of hydroelectric is generated annually.

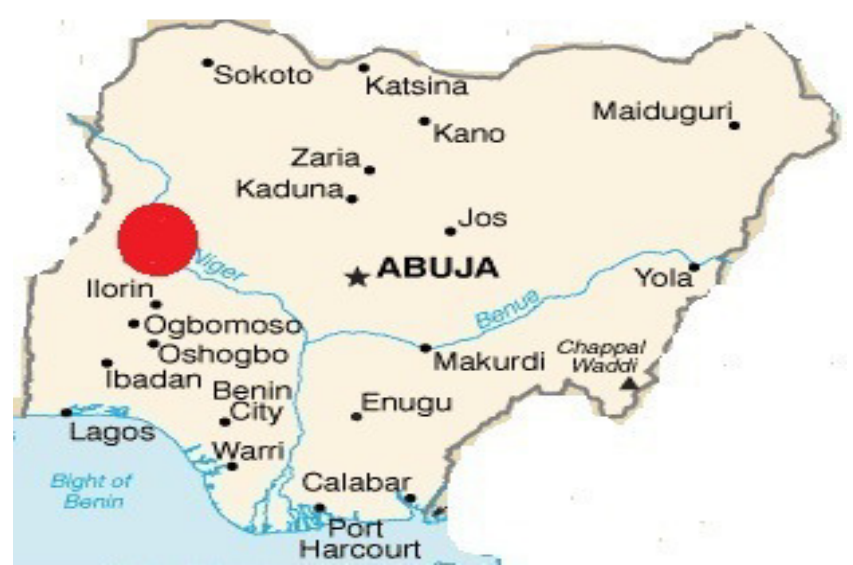

Figure 1: Location of Study Area within the Map of Nigeria

\subsection{Model Selection}

The physically based model used in this study is the Soil and Water Assessment Tool (SWAT) and the justification is the data availability and good documentation. Its efficacy in prediction of different hydrological processes has been reported in many studies $[8,9,10,11]$. The presence of several user group such as SWAT Africa, SWAT world and Waterbase Google group where users from different part of the world share their research problems and modeling experience with SWAT is an appealing incentive tool among researchers in this area of study. 


\subsubsection{Description of SWAT Model}

SWAT was originally developed by the United States Department of Agriculture (USDA) to predict the impact of land management practices on water, sediment and agricultural chemical yields in large ungauged basins [12]. The SWAT model is a catchment-scale continuous time model that operates on a daily time step with up to monthly/annual output frequency.

The major components of the model include weather, hydrology, erosion, soil temperature, plant growth, nutrients, pesticides, land management, channel and reservoir routing. It divides a catchment into subcatchments. Each sub-catchment is connected through a stream channel and further divided into a Hydrologic Response Unit (HRU). The HRU is a unique combination of a soil and vegetation types within the sub-catchment. The model calculations are performed on a HRU basis and flow and water quality variables are routed from HRU to subbasin and subsequently to the watershed outlet. The simulation of hydrologic cycle by SWAT is based on the water balance equation:

$$
\begin{gathered}
S W_{t}=S W_{o}+\sum_{i=1}^{t}\left(R_{\text {day }}-Q_{\text {surf }}-E_{a}-W_{\text {seep }}\right. \\
\left.-Q_{g w}\right)_{i}
\end{gathered}
$$

where $\mathrm{SW}_{\mathrm{t}}$ is the final soil water content (mm water), $\mathrm{SW}_{\mathrm{o}}$ is the initial soil water content in day $\mathrm{i}(\mathrm{mm}$ water), $\mathrm{t}$ is the time (days), $\mathrm{R}_{\text {day }}$ is the amount of precipitation in day i ( $\mathrm{mm}$ water), $\mathrm{Q}_{\text {surf }}$ is the amount of surface runoff in day i (mm water), Ea is the amount of evapo-transpiration in day $\mathrm{i}\left(\mathrm{mm}\right.$ water), $\mathrm{W}_{\text {seep }}$ is the amount of water entering the vadose zone from the soil profile in day i ( $\mathrm{mm}$ water), and $\mathrm{Q}_{\mathrm{gw}}$ is the amount of return flow in day i (mm water). The estimation of surface runoff can be performed by the model using two methods. These are the SCS curve number procedure of USDA Soil Conservation Service and the Green \& Ampt infiltration method [12]. The SCS curve number is described by:

$$
Q_{\text {surf }}=\frac{\left(R_{\text {day }}-0.2 S\right)^{2}}{\left(R_{\text {day }}+0.8 S\right)}
$$

In which, $Q_{\text {surf }}$ is the accumulated runoff or rainfall excess $(\mathrm{mm}), R_{\text {day }}$ is the rainfall depth for the day $(\mathrm{mm}), \mathrm{S}$ is the retention parameter $(\mathrm{mm})$.

The retention parameter is defined by Equation 3

$$
S=25.4\left(\frac{100}{C N}-10\right)
$$

where, $\quad Q$ is the daily surface runoff $(\mathrm{mm})$ : $\quad R$ is the daily rainfall $(\mathrm{mm}), \quad S$ is the retention parameter
( $\mathrm{mm}$ ) and $\mathrm{CN}$ is the curve number.

The prediction of lateral flow by SWAT model is done using Equation 4

$$
q_{\text {lat }}=0.024 \frac{(2 S S C \sin \propto)}{\theta_{d} L}
$$

In (4), $\mathrm{q}_{\text {lat }}=$ lateral flow (mm/day); $\mathrm{S}=$ drainable volume of soil water per unit area of saturated thickness (mm/day); $\quad \mathrm{SC}=$ saturated hydraulic conductivity ( $\mathrm{mm} / \mathrm{hr}) ; \mathrm{L}=$ flow length, $\alpha=$ slope of the land, $\theta_{d}=$ drainable porosity.

The estimation of the base flow is done using Equation 5

$$
\begin{aligned}
Q_{g w j}=Q_{g w j-1} & \cdot e^{\left(-\alpha_{g w} \cdot \Delta t\right)} \\
& +w_{r c h r g} \cdot(1 \\
& \left.-e^{\left(-\alpha_{g w} \cdot \Delta t\right)}\right)
\end{aligned}
$$

where $Q_{g w j}$ is the groundwater flow into the main channel on day j; $\alpha_{\mathrm{gw}}$ is the base flow recession constant; $\Delta \mathrm{t}$ is the time step and $\mathrm{W}_{\text {rchrg }}$ is the amount of recharge entering the shallow aquifer.

\subsection{Model Inputs}

One of the major issues encountered in the application of hydrologic models in developing countries is the lack of required data for model input. In order to overcome these challenges, hybrid data was used in the creation of database in this study. This involves combining local and in-situ data gathered from local agencies and global data obtained from organizations or global database. In some cases, data collection was also carried out at the selected locations within the watershed area and the information obtained used to update the online global database.

\subsubsection{Digital Elevation Model (DEM)}

The $90 \mathrm{~m}$ resolution topography data (see Figure 2) used for this study was extracted from the Shuttle Radar Topography Mission (SRTM) final version developed by [13]. The CGIAR-CSI GeoPortal is able to provide SRTM 90m Digital Elevation Data for major part of the entire world. The SRTM digital elevation data provided has been processed to fill data voids and to facilitate its ease of use by a wide group of potential users. This data is provided in an effort to promote the use of geospatial science and applications for sustainable development and resource conservation in the developing world [13]. The DEM provides the basis for watershed delineation into sub-basins. Also, topographic parameters such as terrain slope, channel slope and reach length are derived from the DEM. 


\subsubsection{Land Use and Land Cover (LULC)}

Land use map needed to run SWAT was extracted from the Global Land Cover Characterization (GLCC) database and used to estimate vegetation and other parameters representing the watershed area. The GLCC database was developed by United State Geological Survey and has a spatial resolution of $1 \mathrm{Km}$ and 24 classes of land use representation [14]. The watershed area was also visited to obtain on-site information about the land use and land cover of the area. Information gathered during the trip was used to update the GLCC database in order to arrive at the final map for the study (Figure 3).

\subsubsection{Soil Data}

Digital soil data for the study was extracted from harmonized digital soil map of the world (HWSD v1.1) produced by Food and Agriculture Organization of the United Nations [15]. The digitized soil map was completed in January 2003 and the database provides data for 16,000 different soil mapping units containing two layers (0 - $30 \mathrm{~cm}$ and $30-100 \mathrm{~cm}$ depth).

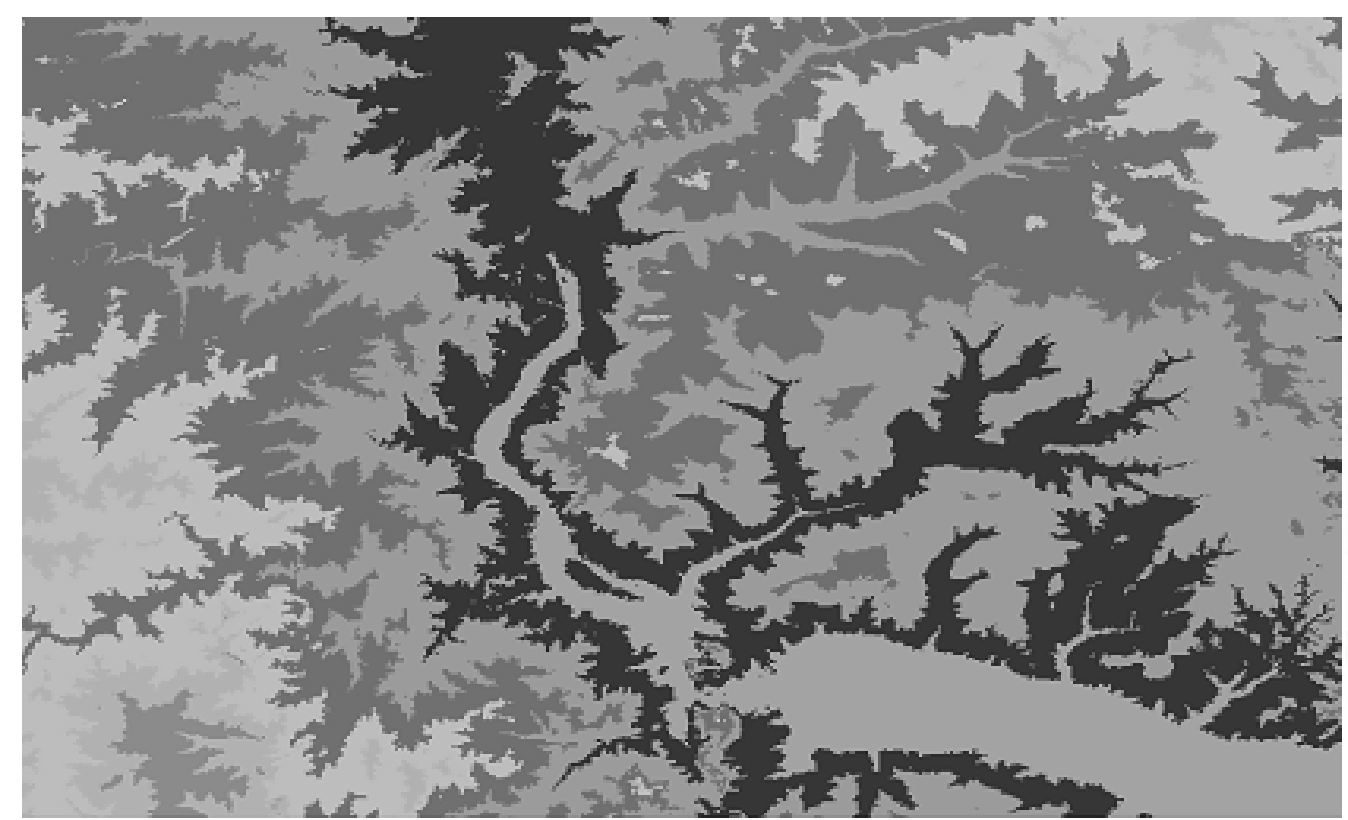

Figure 2: Digital Elevation Model (DEM) of the watershed area

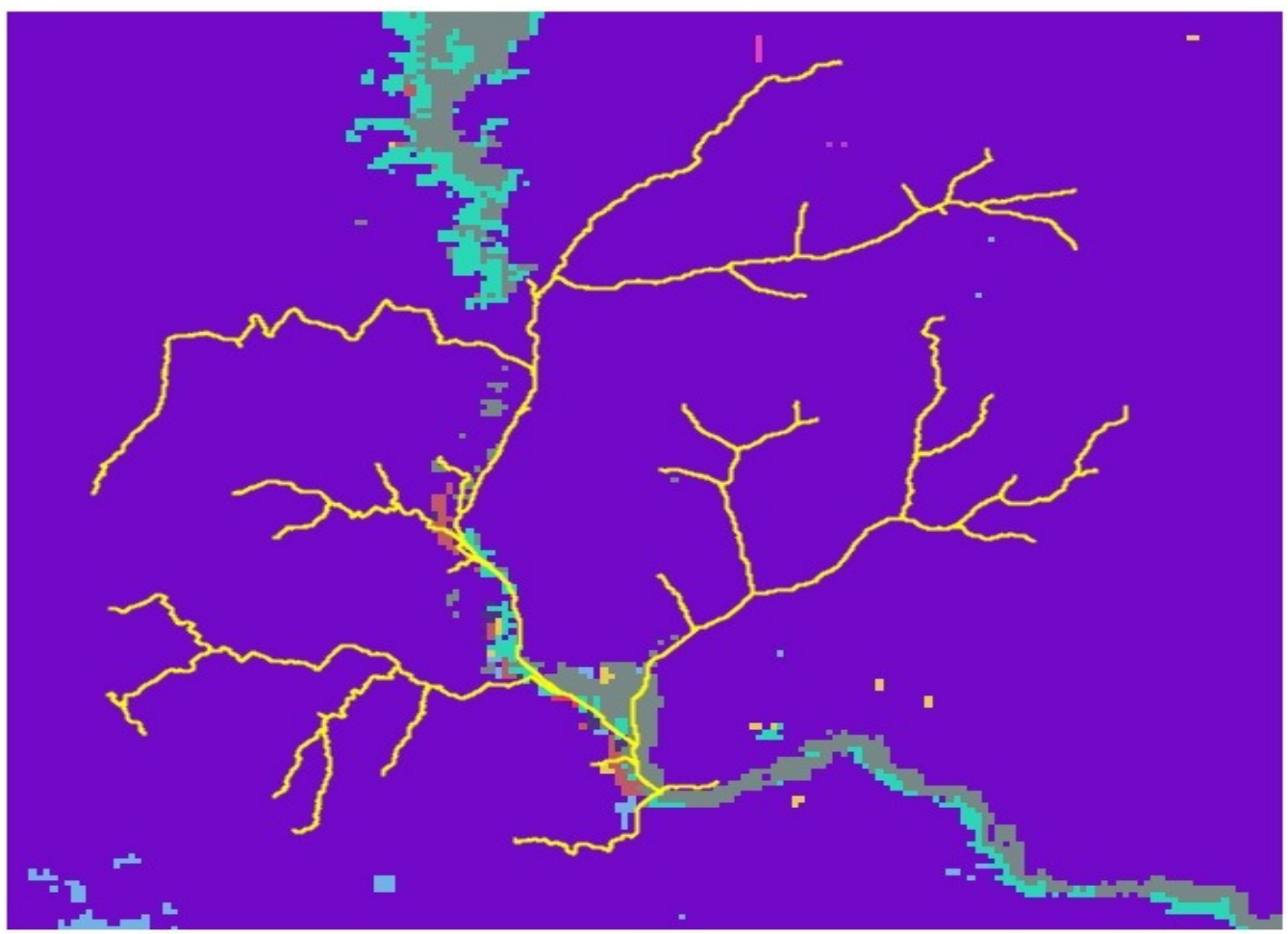

Figure 3: Land use Map of the watershed area
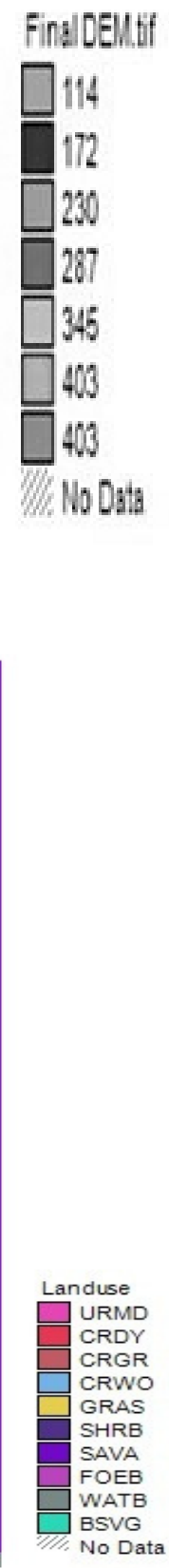

Vol. 33, No. 3, July 2014 
Seven soil units are then extracted from the database and completed by additional information gathered by taken soil samples from different locations within the watershed area. 16 soil samples were collected from two different layers ( $0-30 \mathrm{~cm}$ and $30-100 \mathrm{~cm}$ depth) and the samples were analyzed and used to update the model parameters.

\subsubsection{Meteorological Data}

Meteorological data needed to run SWAT were obtained from authorities of Nigerian Meteorological Agency (NIMET) and Jebba Hydropower station. These data include daily precipitations, maximum and minimum temperature, solar radiation and relative humidity. The collected weather variables for driving the hydrological balance within the watershed are from the period 1988 to 1995. For missing data, a weather generator embedded in the SWAT model was used to fill the gaps. The weather generator input file contains the statistical data needed to generate representative daily climate data for the subbasins [12]. The modeling software, MapWindowSWAT (MWSWAT) supports the use of one weather generator file, which is then used for all subbasins, or a weather generator table, which contains the parameters for a number of weather stations each represented by one line in the table. Details of the parameters in the weather generator file and how they are estimated can be found in [16]

\subsection{Model Configuration and Setup}

The configuration and setting up of MWSWAT modeling starts with the projection of all required spatial datasets to the same projection called UTM Zone $31 \mathrm{~N}$ Northern Hemisphere, which is the Universal Transverse Mercator projection parameters for the selected watershed area in Nigeria using GIS interface of the modeling tool. Other steps involved in the configuration and setting up of model are as explain as follows:

\subsubsection{Watershed Delineation}

To start the delineation process, the Automatic Watershed Delineation (AWD) dialogue box was launched from the model interface and the base DEM selected by browsing to the file location. The elevation units was set to meters and this should be applicable to the base DEM. Focusing mask which encapsulates the watershed were drawn and saved as a shape file. The threshold size of the subbasins was set for the model and this can be set by area, in various units (sq $\mathrm{km}$, hectare) or by number of cells. For this study, a threshold value of $100 \mathrm{Km}^{2}$ is used.

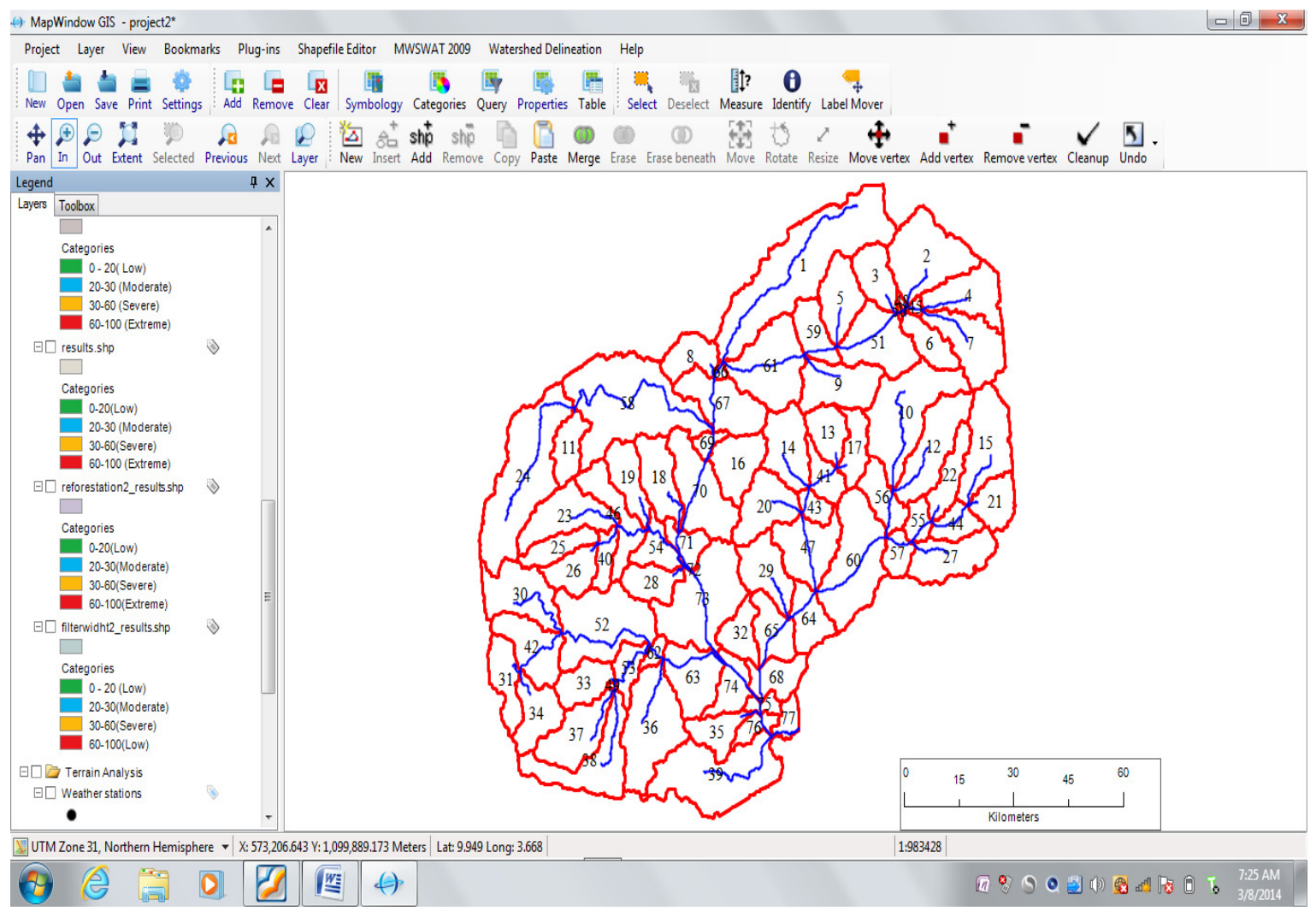

Figure 4: Showing the GIS interface of the delineation of study area into sub-basins 
In other to complete the settings for watershed delineation, an outlet point, which should be in the form of a shape file need to be created and selected. For the selected watershed, a total number of 77 sub-basins were delineated after running the AWD and this is subsequently divided into 107 HRUs each with unique combination of land-use, slope and soil. Figure 4 shows the result of the delineation of the watershed into subbasins.

\subsubsection{SWAT Setup and Run}

This step involves the settings of the simulation period (start and finish date) and the selection of the weather sources from the SWAT data base. The option to choose the methods for the estimation of surface runoff (Curve Number or Green and Ampt method), channel water routing (variable or Muskingum method), potential evapo-transpiration (Priestley,Penman-Monteith, Hargreaves) are available. SWAT was executed using the Runoff Curve Number method for estimating surface runoff from precipitation, the Hargreaves method for estimating potential evapo-transpiration generation, and the Variable-storage method to simulate channel water routing. The simulation period is from 01 January 1988 to Dec 31 1995. Modeling data for the first two years were used to inialise the model while those from 1990 to 1995 were used for the calibration and validation of the model. All the necessary files needed to run SWAT were written at this level and the appropriate selection of weather sources done before running the SWAT executables.

\section{RESULTS AND DISCUSSION}

\subsection{Parameter Sensitivity Analysis}

Sensitivity Analysis of model parameters was carried out using SWAT2009 interface. This involves specification of the SWAT simulation that will be used for performing the sensitivity analysis and the location of the sub-basin where observed data would be compared against simulated output. The sensitivity analysis based on surface runoff showed that the most sensitive parameters for hydrology modeling of upstream watershed of Jebba dam are curve number $\left(\mathrm{CN}_{2}\right)$, threshold water depth aquifer (GWQMN), soil evaporation compensation factor (ESCO) and soil available water capacity (SOL_AWC). Other SWAT parameters considered during the sensitivity analysis were the Soil available water capacity; $\mathrm{CH}_{-} \mathrm{K} 2$ : Channel effective hydraulic conductivity; Sol_z: Soil Depth; GW_REV: Groundwater "revap" coefficient; epco: Plant uptake compensation factor; Blai: Maximum potential leave area index; Alpha_Bf: Base flow Alpha factor.(see Figure 5) This result is in tandem with those found by many similar studies $[16,1,17]$, confirming that these four parameters are crucial for water balance and stream flow calibration [18]. In total, 14 parameters were selected for calibration through the Parasol optimization method [19]. Defining the optimal values of model variables automatically is time consuming but it has been shown to be more efficient and reliable than the manual procedure $[20,21]$

\subsection{Performance Evaluation, Calibration and Validation of Model}

Running SWAT model with the specified optimal values allow measuring the performance of the model. This is done by comparing the observed and simulated monthly inflow at the Jebba gauge station for both the calibration and validation periods. The model was calibrated with the observed monthly inflow of Jebba Lake from 1990 to 1992 and validated with another set of independent data set from 1993 -1995. The results of the calibration and validation exercise are as presented in Figure 6 and 7 respectively. Performance evaluation of the model using the statistical methods of coefficient of determination $\mathrm{R}^{2}$ and Nasch-Sutcliffe Efficiency (NSE) showed a good correlation between the simulated and observed data with $\mathrm{R}^{2}$ and NSE 0.76 and 0.72 respectively for calibration period. The validation period values of $\mathrm{R}^{2}$ and Nasch-Sutcliffe Efficiency (NSE) are 0.71 and 0.78 respectively.

\section{CONCLUSION AND RECOMMENDATION}

SWAT model was successfully calibrated and validated at the upstream watershed of Jebba Lake in the north central Nigeria. The model produced good simulation results for monthly average stream flow as well as for other water balance components. The auto-calibration method based on PARASOL (Parameter Solution) was used to calibrate the model while performance evaluation of the model was carried out successfully with the recommended statistical coefficients.

In this context, the comparison of observed and simulated flow stream revealed a Nash-Sutcliffe coefficient and $\mathrm{R}^{2}$ superior to 0.7 for both calibration and validation periods. These performances can be enhanced furthermore using more accurate input data especially for the soil and land-use of the area that were estimated in this study with global data. The integration of some other climatic data such as solar radiation, humidity and wind can also improve the accuracy of the modeling results.

Vol. 33, No. 3, July 2014 


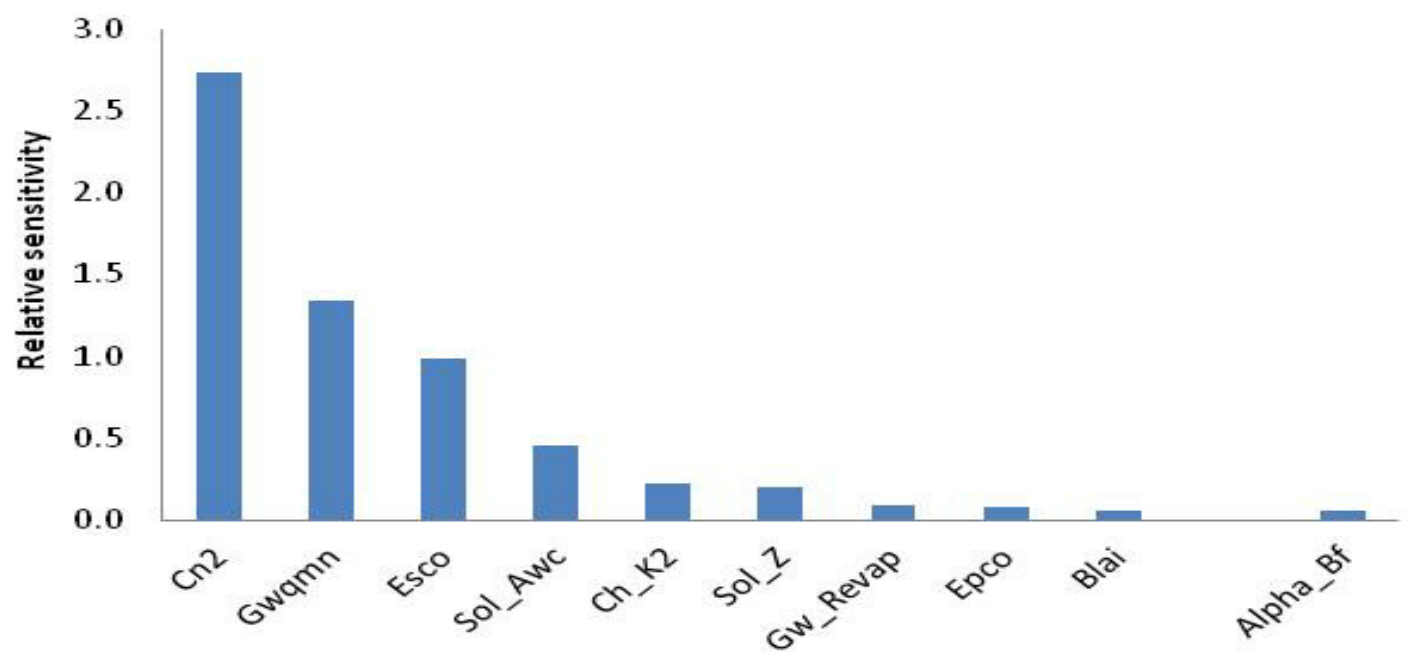

Figure 5: Information on relative sensitivity and description of modeling parameters

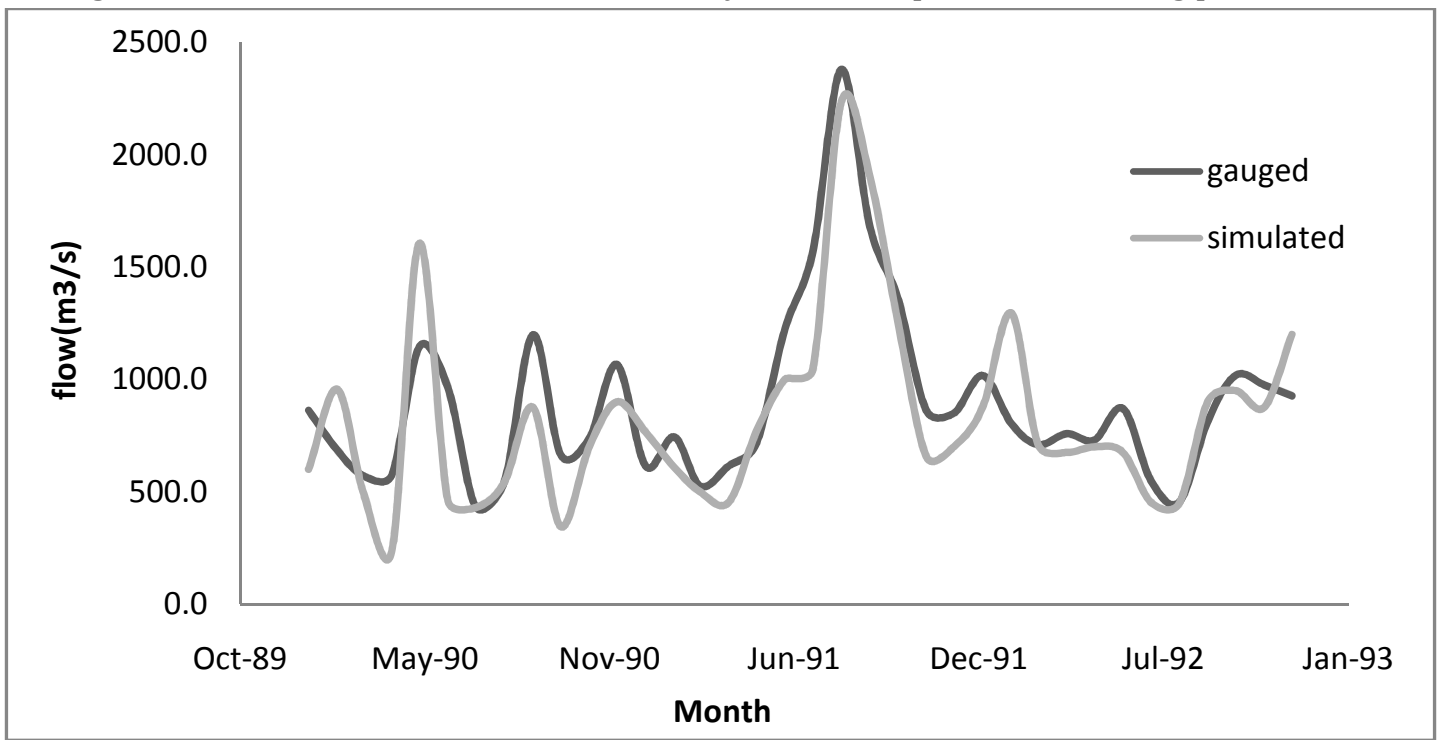

Figure 6: Simulated and Observed flows during the calibration period (1990-1992)

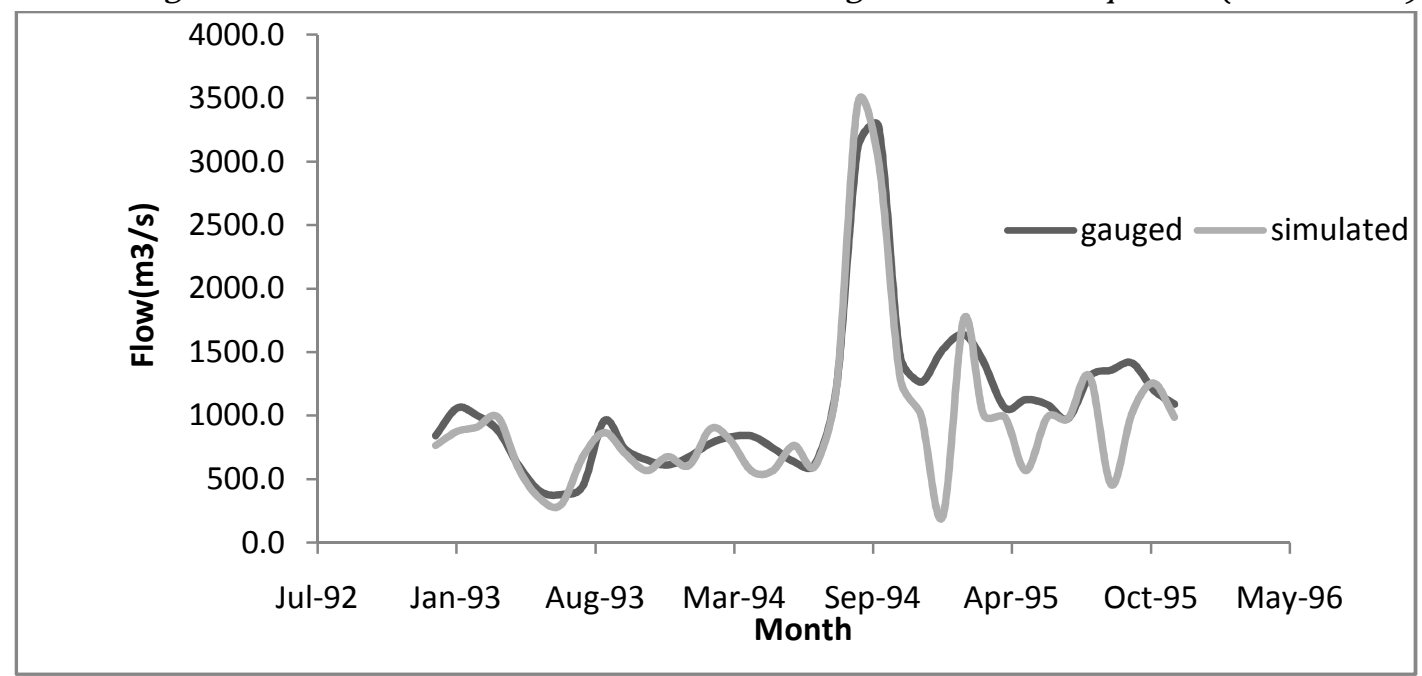

Figure 7: Simulated and observed flows during the validation period (1993-1996)

This study had demonstrated the utility of the remote sensing and GIS to create, combine and generate the necessary data to set up and run the hydrological models especially for those distributed and continuous. It had also showed the ability of SWAT model to simulate and predict the stream flow in river 
basins in Nigeria which can aid sustainable management of water resources of the catchment.

\section{ACKNOWLEDGEMENT:}

This research was supported by the International Foundation for Science (IFS), Stockholm Sweden, through a grant with agreement No W/5382-1 to A.G Adeogun. Also, the support of the National Centre for Hydropower Research and Development, University of Ilorin, Ilorin, Nigeria towards the successful completion of this study is hereby acknowledged.

\section{REFERENCES}

[1] Fadil, A., Rhinane, H., Kaoukaya, A.,Kharchaf, Y., and Bachir, O.A. "Hydrologic Modeling of the Bouregreg Watershed (Morocco) Using GIS and SWAT Model" Journal of Geographic Information System vol 3, 2011, pp279-289

[2] Miloradov, M. and Marjanovic, P. "Guidelines for conducting water resources assessment". A contribution to the International Hydrological Programme within Project M.1-1(a) (IHP-IV). United Nations Educational, Scientific and Cultural Organization, Paris 1998

[3] Xu, C.Y. and Singh, V.P. "Review on Regional Water Resources Assessment Models under Stationary and Changing Climate". Water Resources Management vol. 18, 2004, pp591-612

[4] Arnold,J.G., Williams, J.R., and Maidment, D.R. “ Continuous-time water and sediment-routing model for large basins". Journal of Hydraulic Engineering, Vol.121, No 2, 1995 pp 171-183.

[5] Sharpley, A.N. and Williams E.D "EPIC Erosion Probability Impact Calculator, Model Documentation," by U.S Department of Agriculture, Agricultural Research Service, Texas, USA, 1990

[6] van Griensven, A., Ndomba, P.M., Yalew, and S., Kilonzo, F. "Critical review of the application of SWAT in the upper Nile Basin countries". Hydrology and Earth System Science Discussions, Vol.9, 2012, pp 3761-3788

[7 ] Alansi, A.W., Amin, M.S.M, Abdul Halim, G., Shafri, H.Z.M., and Aimrun., W. (2009) "Validation of SWAT model for stream flow simulation and forecasting in Upper Bernam humid tropical river basin, Malaysia". Hydrology Earth System Science, Vol.6, pp7581-7609

[8] Omani.N,Tajrishy, M., and Abrishamchi, A. "Modeling of a River Basin Using SWAT Model and SUFI-2". 4th International Conference of SWAT Model UNESCOIHE Delft, Netherlands July 4-6 2007

[9] Ndomba, P.M, Griensven, A. "Suitability of SWAT Model for Sediment Yields Modelling in the Eastern Africa, Advances in Data, Methods, Models and Their Applications in Geoscience", Dongmei Chen (Ed.), ISBN: 978-953-307-737-6, InTech, Available from:

http://www.intechopen.com/articles/show/title/s uitability-of-swat-model-for-sediment-yieldsmodelling-in-the-eastern-africa:261-284.

[10] Birhanu, B.Z. "Hydrological modeling of the Kihansi river catchment in South Central Tanzania using SWAT model". International Journal of Water Resources and Environmental Engineering Vol.1, Number 1,2009,pp 001-010

[11] Ayana, A.B.,Edossa, D.C, and Kositsakulchai. E. "Simulation of Sediment Yield using SWAT Model in Fincha Watershed, Ethiopia. Kasetsart Journal of Natural Science Vol. 46, 2012,pp283 - 297

[12] Arnold, J.G, Kiniry, J.R, Srinivasan, R., Williams, J.R., Haney, E.B.,and Neitsch, S.L. "Soil and Water Assessment Tool Input Output File Documentation". Soil and Water Research Laboratory, Agricultural Research Service, Grassland, 808 East Blackland Road, Temple, Texas 2011

[13] CGIAR (2012) SRTM 90m Digital Elevation Data (2012) http://srtm.csi.cgiar.org/, Accessed on $4^{\text {th }}$ April, 2013

[14] GLCC(2012) http://edc2.usgs.gov/glcc/glcc.php. Assesed on 8th May 2013

[15] Nachtergaele, F., Velthuizen, H.V., and Verelst. L. Harmonized World Soil Database (HWSD). Food and Agri-culture Organization of the United Nations, Rome www.fao.org/nr/water/docs/harm-worldsoil-dbv7cv..Pdf accessed on May 30, 2013

[16] Schuol, J., and Abbaspour, K.C. "Using monthly weather statistics to generate daily data in a SWAT model application to West Africa". Ecological Modeling Vol. 201, 2007,pp 301-311

[17] Stehr, A.,Debels, P.,Romero, F., and Alcayaga, H. "Hydrological modelling with SWAT under conditions of limited data availability: evaluation of results from a Chilean case study" Hydrological Sciences-Journal-des Sciences Hydrolgiques, Vol.53,Number 3, 2008,pp 588-601

[18] Setegn, S.G, Srinivasan, R., and Dargahi, B. "Hydrological Modelling in the Lake Tana Basin, Ethiopia Using SWAT Model". The Open Hydrology JournalVol.2, 2008, pp 49-62

[19] White, K.L and Chaubey, I. "Sensitivity Analysis, Calibration, and Validations for a Multisite and Multivariable SWAT Model" Journal of the American Water Resources Association, Vol. 41, Number 5, 2005 pp. 1077-1089.

[20] Amenaghawon, N. A. Osagie, E. I, Osemwengie S. O. and Okeimen, C. O. "Modelling and simulation of batch hydrolysis of Acetic Anhydride to produce Acetic Acid", Nigerian Journal of Tecnology, Vol. 32, No. 3, 2013, pp. 386-392

[21] Otun, J. A, Munta S. and Adie D. B. "Modelling flow over stepped spillway with varying chute geometry" Nigerian Journal of Technology, Vol. 31, No. 2, 2012, pp. $206-212$. 